\title{
Transportation Investments and Productivity Analysis of a Japanese Case Study
}

\author{
Atsushi Koike ${ }^{1, *}$, and Ryota Okumura ${ }^{1}$ \\ ${ }^{1}$ Department of Civil Engineering, Kobe University, 1-1 Rokkodai Nadaku Kobe, Japan
}

\begin{abstract}
Over the last two decades, there have been several studies on productivity related to transportation investments in not only Japan but also several foreign countries. However, these prior studies did not achieve common results as they did not use a unified format for measuring the service level of the transportation network and using the dataset. Therefore, this study classifies previous studies from six points of view. These are analytical method, functional type, explained variable, service level of the transportation network, aggregation level, and estimation method. This study examines the differences in results caused by the diversity of analytical methods. In addition, this study estimates the production function using two analytical methods with Japanese data. Then, the relationship between the productivity and transport investments is revealed. From this result, several issues are confirmed.
\end{abstract}

\section{Introduction}

In the last two decades, there have been several studies about productivity related to transportation investments in not only Japan but also several foreign countries, because it is assumed that transportation investments have a significant effect on economic growth. Aschauer [1] is the first study that considered the relationship between aggregate productivity and government expenditures in public-sector capital stock including transportation investments. The study revealed that the public capital stock had most explanatory power for productivity. The method of statistically estimating the production function including the level of service was established in the United States. Later, the relationship between the level of service and productivity was studied using a similar method in Japan. However, most prior studies have not used a unified format for this issue because of the difference in the estimation process and dataset. For example, Kanemoto and Okawara [2] revealed that public investments had a negative effect on production in 1985. Yoshino et al. [3] revealed that the marginal productivity of public investments decreased from 1970 to 1993. (See Ejiri et al. [4], Tsukai et al. [5], and Hayashi [6] for more information.) Thus, it is necessary to establish a method of estimation of the production function considering the service of the transportation investments; it is also necessary to lead to a robust opinion.

*Email address: koike@lion.kobe-u.ac.jp 
In contrast, OECD published a manual [7] on the method of measuring productivity. The purpose of this manual was to solve the problem of the difference in the estimation process. Thus, the change in productivity can be compared on an international level using this manual. However, this manual does not consider the formulation of the transportation service. In response, the purpose of this study is to establish the normal analytical method of the production function including the formulation of the transportation service. Therefore, this study indicates problems in each analytical method and analytical results using Japanese data.

\section{Classification of prior studies}

This chapter classifies the prior studies using six points (see Fig. 1.).

\begin{tabular}{|c|c|c|}
\hline Analytical method & Functional type & Explained variable \\
\hline $\begin{array}{l}\text { - Time-series analysis } \\
\text { - Cross-section analysis } \\
\text { - Panel analysis }\end{array}$ & $\begin{array}{l}\text { - Cobb-Douglas type } \\
\text { - CES type } \\
\text { - Translog type }\end{array}$ & $\begin{array}{l}\text { - Gross output } \\
\text { - Value-added }\end{array}$ \\
\hline $\begin{array}{c}\text { Service level of the } \\
\text { transportation network }\end{array}$ & Aggregation level & Estimation method \\
\hline $\begin{array}{l}\text { - Amount of Investments } \\
\text { - Accessibility }\end{array}$ & $\begin{array}{l}\text { - Industry level } \\
\text { - Region level }\end{array}$ & $\begin{array}{l}\text { - One-step estimation } \\
\text { - Two-step estimation }\end{array}$ \\
\hline
\end{tabular}

Fig. 1. Classification points

\subsection{Analytical method}

There are three types of analytical methods. The first method is time-series analysis, which involves regression analysis using the data with time change. For this, it is assumed that parameters, such as the social or industrial structure, are constant for the time change. It is not useful to use the time-series analysis for a long period.

The second analytical method is cross-section analysis, which involves regression analysis using the data with region change. For this, it is assumed that the parameters are constant for the region change. This analysis is used by remaining constant with the timeseries analysis, and it needs data by region.

The third analytical method is panel analysis, which involves regression analysis using the data with both time and region change. Thus, panel analysis is a combination of timeseries and cross-section analyses. For this analysis, it is assumed that the parameters are constant for both time and region change. Therefore, the assumption of panel analysis is stronger than that of both time-series and cross-section analyses.

\subsection{Functional type}

Three main functional types are used for estimating the production function. The first is the Cobb-Douglas type, which involves the assumption that the elasticity of substitution is 1 . Therefore, this type is stronger than all other types and is mainly used for estimating the macro production function.

The second is the constant elasticity of substitution (CES) type, which involves the assumption that the elasticity of substitution is constant. Thus, this type is generalized from the Cobb-Douglas type. 
The third is the translog type, which involves the assumption that the elasticity of substitution is flexible. Thus, this type is the most general production function and is often estimated simultaneously with the cost-share function because of too many parameters.

\subsection{Explained variable}

There are two types of explained variables. The first is gross output, which includes not only the final demand but also the intermediate input. Thus, it is necessary to acquire the transaction data of the intermediate products, but it is difficult to acquire this data by industry. This is why gross output is not used often for estimating the production function by industry.

The second explained variable is the value-added. This does not include the intermediate input, so it can be explained by only labor and capital input. The value-added is used more often than gross output.

\subsection{Service level of the transportation network}

There are two types of service level of the transportation network. The first is the amount of investments, which is the government expenditure for public investment. The amount of investments includes flow and stock, but the stock is used as an explanatory variable for estimating the production function. The amount of investments is calculated by the price base, so that this is easily treated together with other explanatory variables.

The second is accessibility, which is derived by the required time and cost. Thus, this index can reveal the effect of the transportation service. However, the accessibility is derived in many different forms, variables, and units. Therefore, this index itself indicates variety.

\subsection{Aggregation level}

The aggregation level includes the industry and region levels. First, this section explains the industrial aggregation. When industries are aggregated, the industrial movement cannot be observed. Thus, the change of productivity of dataset aggregated industries is lower than that with dataset by industry. In addition, it is difficult to acquire the necessary dataset by industry.

Second, this section explains the regional aggregation. This is an important problem to settle at the region level, because the region level relates to the transportation service level. Therefore, the region level decides the range of a transportation investment's effect, which could be at the macro, prefecture, municipality, or firm level. Moreover, it is difficult to acquire the necessary data at the low region level.

\subsection{Estimation method}

There are two types of estimation methods. The first is one-step estimation, which estimates the production function including the explanatory variable of the level of service. Thus, this estimation step is used more often than two-step estimation because of the simple calculation.

The second estimation method is two-step estimation. This method is used in Holl [8], and this section explains this method by using Holl's (2016) model. First, the production function not including the level of service is estimated as the following equation.

$$
\ln Y_{i t}=a_{i t}+\beta_{1} \ln K_{i t}+\beta_{2} \ln L_{i t}+u_{i t}
$$


Here, $Y_{i t}$ : value-added of firm $i$ at time $t, L_{i t}$ : labor input of firm $i$ at time $t, K_{i t}$ : capital stock of firm $i$ at time $t$, and $u_{i t}$ : error of firm $i$ at time $t$.

Second, the following equation including the constant term and error of the estimated production function is estimated as follows.

$$
a_{i t}=\delta \ln H W D I S_{i t}+u_{i t}
$$

Here, $H W D I S_{i t}$ : highway access distance of firm $i$ at time $t$.

The effects of the transportation service are estimated from equation (2). Thus, this estimation method is more complex than one-step estimation because two regressions are necessary.

\subsection{Classification of prior studies}

This section classifies prior studies that estimated the production function including the level of service on the above-discussed six points. Table 1 shows the classification of the prior studies' results.

Table 1. Classification of prior studies*

\begin{tabular}{|c|c|c|c|c|c|c|}
\hline & $\begin{array}{c}\text { Analytical } \\
\text { method }\end{array}$ & $\begin{array}{c}\text { Functional } \\
\text { type }\end{array}$ & $\begin{array}{c}\text { Explained } \\
\text { variable }\end{array}$ & $\begin{array}{c}\text { Service } \\
\text { level }\end{array}$ & Aggregation & $\begin{array}{c}\text { Estimation } \\
\text { method }\end{array}$ \\
\hline $\begin{array}{l}\text { Aschauer } \\
\text { (1989) }\end{array}$ & $\mathrm{T}$ & C-D & $\mathrm{G}$ & I & $\begin{array}{l}1 \text { industry } \\
1 \text { region }\end{array}$ & One \\
\hline $\begin{array}{c}\text { Takenaka } \\
\text { and } \\
\text { Ishikawa [9] }\end{array}$ & $\mathrm{T}$ & C-D & V & I & $\begin{array}{l}1 \text { industry } \\
1 \text { region }\end{array}$ & Two \\
\hline $\begin{array}{c}\text { Asako and } \\
\text { Sakamoto } \\
{[10]}\end{array}$ & $\mathrm{P}$ & C-D & $\mathrm{V}$ & I & $\begin{array}{l}1 \text { industry } \\
42 \text { regions }\end{array}$ & One \\
\hline $\begin{array}{l}\text { Mitsui and } \\
\text { Inoue [11] }\end{array}$ & $\mathrm{T}$ & C-D & V & I & $\begin{array}{l}1 \text { industry } \\
1 \text { region }\end{array}$ & One \\
\hline $\begin{array}{l}\text { Iwamoto et } \\
\text { al. [12] }\end{array}$ & $\mathrm{P}$ & C-D & $\mathrm{V}$ & I & $\begin{array}{l}3 \text { industries } \\
42 \text { regions }\end{array}$ & One \\
\hline $\begin{array}{l}\text { Yoshino and } \\
\text { Nakano [13] }\end{array}$ & $\mathrm{P}$ & $\mathrm{TL}$ & $\mathrm{G}$ & I & $\begin{array}{l}1 \text { industry } \\
9 \text { regions }\end{array}$ & One \\
\hline $\begin{array}{c}\text { Economic } \\
\text { Planning } \\
\text { Agency [14] }\end{array}$ & $\mathrm{T}$ & C-D & V & I & $\begin{array}{l}1 \text { industry } \\
2 \text { regions }\end{array}$ & One \\
\hline $\begin{array}{c}\text { Kanemoto } \\
\text { and } \\
\text { Okawara } \\
(1996)\end{array}$ & $\mathrm{C}$ & C-D & V & I & $\begin{array}{c}1 \text { industry } \\
456 \text { regions }\end{array}$ & One \\
\hline \multirow[t]{2}{*}{$\begin{array}{l}\text { Yoshino et } \\
\text { al. (1999) }\end{array}$} & $\mathrm{T}$ & $\begin{array}{l}\text { C-D } \\
\text { TL }\end{array}$ & $\mathrm{V}$ & I & $\begin{array}{l}1 \text { industry } \\
1 \text { region }\end{array}$ & One \\
\hline & $\mathrm{P}$ & $\mathrm{TL}$ & $\mathrm{V}$ & I & $\begin{array}{c}3 \text { industries } \\
11 \text { regions } \\
\end{array}$ & One \\
\hline $\begin{array}{c}\text { Kim and } \\
\text { Hewings } \\
{[15]}\end{array}$ & $\mathrm{C}$ & TL & $\mathrm{V}$ & Acc & $\begin{array}{l}16 \text { industries } \\
237 \text { regions }\end{array}$ & One \\
\hline Holl (2016) & $\mathrm{C}$ & C-D & V & Acc & Firm-level & Two \\
\hline
\end{tabular}

*Service level: Service level of the transportation network, T: Time-series analysis, C: Cross-section analysis, P: Panel analysis, C-D: Cobb-Douglas type, TL: Translog type, G: Gross output, V: Value-added, I: Amount of investments, Acc: Accessibility, One: One-step estimation, and Two: Two-step estimation 


\section{Analysis}

This chapter explains the analytical method, dataset, and results. This study is composed of two analyses. The first is time-series analysis not including the level of service, and the second is panel analysis including the level of service.

\subsection{First analysis}

The first analysis is time-series analysis for 1970-2009 not including the level of service. Therefore, the estimated production function in this section is composed of labor input and private capital stock, which is the general production function. The production function is a derived Cobb-Douglas type and presented as follows:

$$
\ln Y_{t}-\ln L_{t}=\alpha+\beta\left(\ln K_{t}-\ln L_{t}\right)+u_{t}
$$

Here, $Y$ : real value-added (million yen, price in 2000), $L$ : the annual total actual hours worked (/1000), and $K$ : real private capital stock (million yen, price in 2000). These variables are data estimated by Tokui et al. (2013) [16].

The productivity is derived by the estimated constant term and error. Thus, this index indicates the production efficiency not explained by labor and capital input.

$$
P=\alpha+u_{t}
$$

Here, $P$ : productivity.

The productivity includes the effects of not only the transportation service but also the total level of service.

\subsection{Second analysis}

The second analysis is panel analysis for 1970-2009 of 47 regions including the level of service. This study uses the amount of investments as the level of service. Parameters are constant for time and region change in the panel analysis. However, it is not natural for parameters to remain constant for a long period, such as from 1970 to 2009. Therefore, this study divides the dataset every five years and analyzes the divided panel dataset. The estimated production function is a derived Cobb-Douglas type and presented as follows:

$$
\ln Y_{t r}-\ln L_{t r}=\alpha+\beta\left(\ln K_{t r}-\ln L_{t r}\right)+\gamma \ln G_{t r}+u_{t r}
$$

Here, $G$ : net level of service stock (million yen, price in 2005). This variable is data estimated by Cabinet Office, Government of Japan (estimation of the level of service stock).

The marginal productivity of public investments by time and region is calculated from the estimated parameter as follows:

$$
F_{t r}=\gamma \frac{Y_{t r}}{G_{t r}}
$$

Here, $F_{t r}$ : marginal productivity of the public investments of region $r$ at time $t$.

The marginal productivity of public investments in all of Japan is derived as its weighted average by region.

$$
F_{t}=\theta \cdot F_{t r}
$$




$$
\theta=\frac{Y_{t r}}{\sum_{r} Y_{t r}}
$$

Here, $F_{t}$ : marginal productivity of public investments in all of Japan at time $t$ and $\theta$ : share of the real value-added.

The marginal productivity of public investments is the change in the value-added output resulting from increasing one more unit in the level of service input.

\subsection{Results}

This section indicates results from the first and second analyses as well as implications of the analytical results. Fig. 2 shows the productivity from the first analysis, marginal productivity of public investments in all of Japan from the second analysis, and real public investments (trillion yen, price in 2005) from the Cabinet Office, Government Of Japan (estimation of the level of service stock).

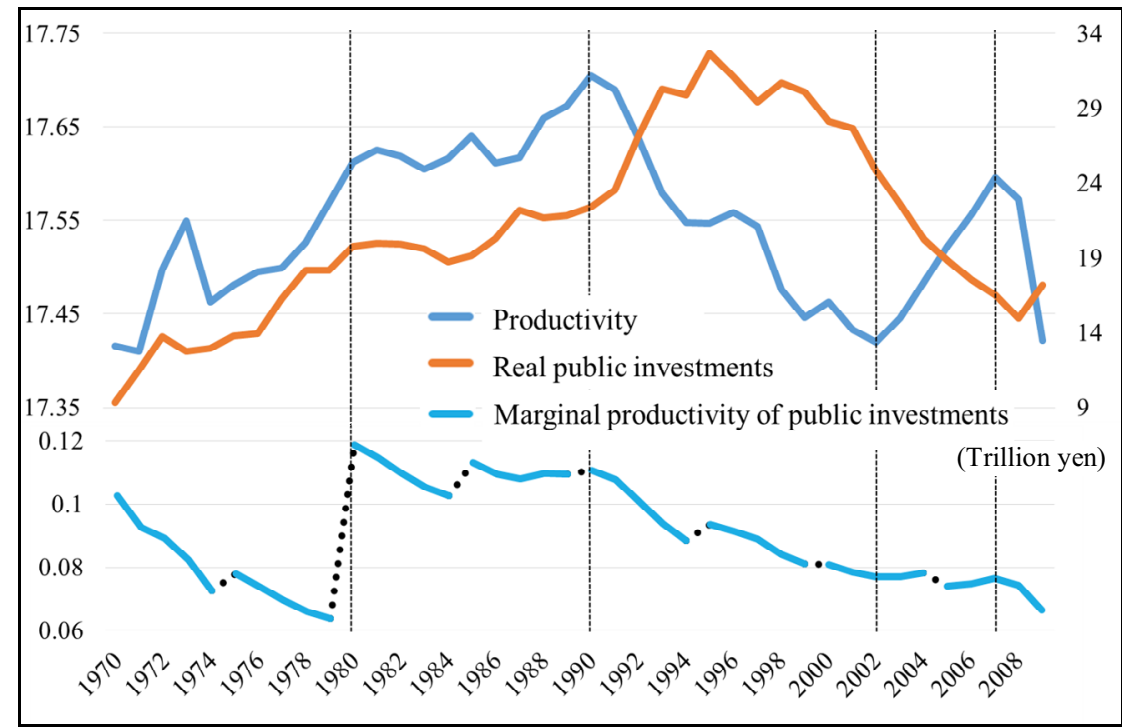

Fig. 2. Productivity, real public investments, and marginal productivity of public investments

In the 1970s, the marginal productivity of public investments decreased as productivity and real public investments increased. In the 1980s, the decline in the marginal productivity of public investments slowed down slightly. In the 1990s, namely after the burst of the economic bubble, the productivity declined dramatically. From 2002 to 2007, productivity increased as real public investments decreased. From 2007 to 2009 , productivity declined because of the decline in the marginal productivity of public investments.

\section{Conclusion}

There are several studies about productivity related to the service level of the transportation network. However, a unified view on this issue is not revealed because of the diversity of analytical methods. This study classifies prior studies using six points of view to reveal this diversity. Each analytical method has individual assumptions and problems. Thus, it is necessary to develop a normal manual on productivity related to the service level of the 
transportation network. Therefore, this study uses Japanese dataset to conduct analyses using two methods and presents the analytical results. The results reveal that the relationship between productivity and public investments, which is used as the level of service in this study, is not constant for the time change.

Next, it is necessary to formulate the transportation investments, because this study does not use transportation investments but total public investments. That means that the results of this study include effects of not only the transportation service but also the level of service other than transportation. Thus, it is necessary to extract the transportation service's effects from the total level of service to reveal the relationship between productivity and transportation investments. Use of the accessibility derived by the required time and cost is considered the solution to this problem.

In addition, it is necessary to continue developing the analytical manual in order to indicate the robust truth about the relationship between productivity and transportation investments.

\section{References}

[1] D. A. Aschauer, Is public expenditure productive?, JME, 23, 177-200 (1989)

[2] Y. Kanemoto, T. Okawara, Is Tokyo too large? An empirical analysis of city sizes in Japan, Central Research Institute of Electric Power Industry, 37, 29-42 (1996)

[3] N. Yoshino, T. Nakajima, M. Nakahigashi, Shakaishihonnoseisanryokukoka, Nippon Hyoron Sha Co., Ltd., 11-88 (1999)

[4] R. Ejiri, M. Okumura, K. Kobayashi, The productivity of infrastructure and economic growth: A state-of-the-art review, JSCE, 688/IV-53, 75-87 (2001)

[5] M. Tsukai, R. Ejiri, M. Okumura, K. Kobayashi, Productivity of infrastructure and spill over effects, JSCE, 716/IV-57, 53-67 (2002)

[6] M. Hayashi, Shakaishihonnoseisanseitodojisei, ESRI, 21 (2002)

[7] P. Schreyer, Measuring Productivity - OECD Manual, Keio University Press (2009)

[8] A. Holl, Highways and productivity in manufacturing firms, JUE, 93, 131-151 (2016)

[9] H. Takenaka, T. Ishikawa, Nihonnoshakaishihonsutokkutokyokyusaido, NLI Research Institute, 6, 19-35 (1991)

[10]K. Asako, K. Sakamoto, Seifushihonnoseisanryokukoka, Japanese Ministry of Finance, IFMP, 26, 97-102 (1993)

[11]K. Mitsui, J. Inoue, Shakaishihonnoseisanryokukoka, Nippon Hyoron Sha Co., Ltd., 43-65 (1995)

[12] Y. Iwamoto, S. Ouchi, T. Takeshita, T. Bessho, Shakaishihonnoseisanseitokokyotoshinochiikikambunseki, Japanese Ministry of Finance, IFMP, 41, 27-52 (1996)

[13]N. Yoshino, H. Nakano, Kokyotoshinochiikikanhaibuntoseisanryokukoka, Japanese Ministry of Finance, IFMP, 41, 41-51 (1996)

[14]Economic Planning Agency, Kaikakuhehonkakukidousurunihonkeizai, EWP, 1.5., 1-5 (1997)

[15]E. Kim, G. J. D. Hewings, An application of an integrated transport network Multiregional CGE model to the calibration of synergy effects of highway investments ESR, 21, 377-397 (2009)

[16] J. Tokui, K. Fukao, T. Makino, T. Miyagawa, N. Arai, S. Arai, T. Inui, K. Kawasaki, N. Kodama, N. Noguchi, R-JIPdetabesunokochikutochiikikanseisanseikakusano bunseki, RIETI, 13-J-037 (2013) 